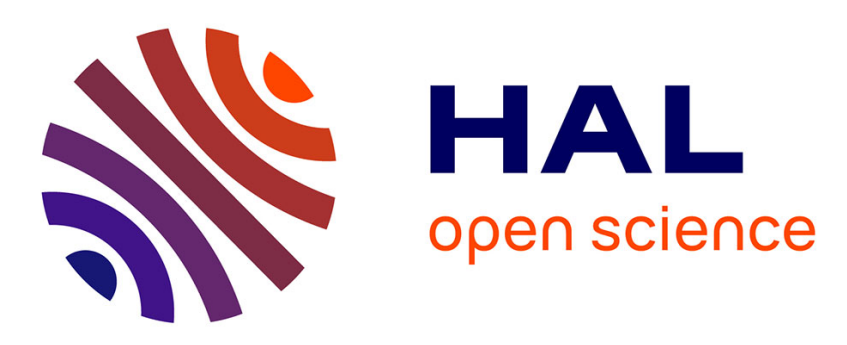

\title{
Sighting of Saccorhiza polyschides (Lightfoot) Batters (Phaeophyceae, Stramenopiles) in Algeria (Mediterranean Sea): an insight into range expansion routes
}

Charles-François Boudouresque, Rachid Semroud, Aurelie Blanfuné, Michèle

Perret-Boudouresque

\section{To cite this version:}

Charles-François Boudouresque, Rachid Semroud, Aurelie Blanfuné, Michèle Perret-Boudouresque. Sighting of Saccorhiza polyschides (Lightfoot) Batters (Phaeophyceae, Stramenopiles) in Algeria (Mediterranean Sea): an insight into range expansion routes. Cryptogamie Algologie, 2020, 41 (5), pp.31-36. 10.5252/cryptogamie-algologie2020v41a5 . hal-02531157

\section{HAL Id: hal-02531157 \\ https://hal.science/hal-02531157}

Submitted on 6 Apr 2020

HAL is a multi-disciplinary open access archive for the deposit and dissemination of scientific research documents, whether they are published or not. The documents may come from teaching and research institutions in France or abroad, or from public or private research centers.
L'archive ouverte pluridisciplinaire HAL, est destinée au dépôt et à la diffusion de documents scientifiques de niveau recherche, publiés ou non, émanant des établissements d'enseignement et de recherche français ou étrangers, des laboratoires publics ou privés. 
Sighting of Saccorhiza polyschides (Lightfoot) Batters (Phaeophyceae, Stramenopiles) in Algeria (Mediterranean Sea): an insight into range expansion routes Charles-François BOUDOURESQUE ${ }^{\mathrm{a}}$, Rachid SEMROUD $^{\mathrm{b}}$, Aurélie BLANFUNÉ ${ }^{\mathrm{a}}$ * \& Michèle PERRET-BOUDOURESQUE ${ }^{\mathrm{a}}$

${ }^{a}$ Aix-Marseille University and University of Toulon, MIO (Mediterranean Institue of Oceanography), CNRS, IRD, Campus of Luminy, Marseilles, France

${ }^{\mathrm{b}}$ Marine Resources Conservation and Valorisation, National School of Marine Science and Coastal Management (ENSSMAL); BP 19, Bois des Cars-Campus Universitaire de Dély Ibrahim, 16320 Alger, Algeria

\begin{abstract}
In the Mediterranean Sea, the north-east Atlantic seaweed Saccorhiza polyschides (Lightfoot) Batters is uncommon. The only permanent populations are located in the Alboran Sea and in the Straits of Messina (Italy). In contrast, since the early 19th century, several sightings, on ship's hulls and/or in harbours, reflect the dispersal of propagules which failed to establish in the Mediterranean. Here we report a new sighting of Saccorhiza polyschides, near the port of Jijel, Algeria. This first new record in the Mediterranean for more than a century indicates that the dispersal of propagules continues today. In addition, because of its spectacular size and ease of its observation, it sheds light on the expansion routes of a species at the limit of their current range area.
\end{abstract}

\title{
Keywords: Algeria / Biogeography / Mediterranean Sea / Range expansion / Saccorhiza polyschides
}

\section{RÉSUMÉ}

Observation de Saccorhiza polyschides (Lightfoot) Batters (Phaeophycées, Straménopiles) en Algérie (mer Méditerranée) : une illustration des voies d'expansion de l'aire de distribution. En Méditerranée, la macroalgue du nord-est de l'Atlantique Saccorhiza polyschides (Lightfoot) Batters n'est pas commune. Les seules populations permanentes sont celles de la mer d'Alboran, près du détroit de Gibraltar, et du détroit de Messine (Italie). Depuis le début du xixe siècle, plusieurs observations, sur des coques de bateaux ou dans des ports, traduisent la dispersion de propagules en Méditerranée ; l'espèce n'y a pas dépassé le stade d'adventice. L'observation de Saccorhiza polyschides près du port de Jijel (Algérie), la première nouvelle observation en Méditerranée depuis plus d'un siècle, montre que la dispersion de propagules en Méditerranée se poursuit de nos jours. De plus, grâce à sa taille et à la facilité de son observation, elle contribue à illustrer les voies d'expansion d'une espèce à la limite de son aire actuelle de distribution.

* Corresponding authors: charles.boudouresque@ mio.osupytheas.fr and aurelie.blanfune@mio.osupytheas.fr.

\section{Introduction}

The brown alga Saccorhiza polyschides (Lightfoot) Batters (Phae- ophyceae, ochrophyta, kingdom Stramenopiles) (synonym of Saccorhiza bulbosa (Hudson) de la Pylaie) is a north-eastern Atlantic large seaweed, known from norway to southern Morocco (Hamel 1931-1939; Gayral 1966; norton \& Burrows 1969; Ardré 1970; norton 1977; rueness 1977). It is a species with a short life-span: the longevity of the macroscopic sporogenic phase $(2 \mathrm{n})$ never exceeds one year; the gametogenic phase is micro- scopic and is dependent on the 
presence of encrusting corallines (rhodobionta, kingdom Archaeplastida) to thrive (Feldmann 1934; Huvé1958; Fredj \& Giaccone 1995; see Boudouresque 2015, for the taxonomic treatment). records from the Gulf of Guinea (Beauvois 1805) and Lanzarote (canary Islands; Ballesteros et al. 1992) could correspond to casual populations stemming from individuals transported on ships' hulls, as is the case for most Mediterranean records (see opposite) (norton \& Burrow 1969; Price et al. 1978).

In the Mediterranean Sea, $S$. polyschides is extremely rare

or almostnon-existent, with the exception of certain areas of the Alboran Sea, close to the Straits of Gibraltar (Feldmann 1934; norton 1977; navarro \& Gallardo 1989; Boudour- esque et al. 1990; ribera et al. 1992; Benhissoune et al. 2002). A permanent population is present in the Straits of Messina (Sicily and calabria, Italy); it thrives mainly on the vertical faces of the blocks of harbour jetties, from sea level down to 2 m depth (Molinier \& Picard 1953; Huvé 1958; Giaccone 1969; Fredj \& Giaccone 1995). Mediterranean specimens are generally smaller than those of the Atlantic: less than $2 \mathrm{~m}$ vs up to $5 \mathrm{~m}$ (Feldmann 1934; cormaci et al. 2012).

Saccorhiza polyschides has sometimes been observed in the Mediterranean (table 1; Fig. 1). However, with the exception of the Alboran Sea and the Straits of Messina, no permanent populations have been recorded. It was observed on ship hulls, on harbour jetties or in the close vicinity of a harbour (Sauvageau 1918; Feldmann 1934). The populations were temporary: the following year, the species was no longer observed, a feature that is indicative of a failed introduction process (Feldmann 1934; Boudouresque et al. 1990; ribera \& Boudouresque 1995; Boudouresque \& Verlaque 2012).

In Algeria, Saccorhiza polyschides has been never observed (Perret-Boudouresque \& Seridi 1989; ouldAhmed et al. 2013). The record of debray (1897) from cherchell, $89 \mathrm{~km}$ west of Algiers, is erroneous (table 1); Jean Feldmann, who examined the voucher specimens of the debray herbarium, corrected the identification into Phyllaria reniformis (Lamouroux) rostafinsky ex Bornet (now Phyllariopsis brevipes (c.Agardh) E.c.Henry \& G.r.South) (Feldmann 1934; Perret-Boudouresque \& Seridi 1989). It is worth noting that the Moroccan populations of cabo tres Forcas are located only $60 \mathrm{~km}$ away from Algeria (González-García 1994).

Table 1. Mediterranean records of Saccorhiza polyschides. Records from the Alboran Sea, close to the Straits of Gibraltar, are not reported.

\begin{tabular}{|c|c|c|c|}
\hline Country & Site & Habitat and comments & References \\
\hline France & Banyuls (Occitania) & $\begin{array}{l}\text { Erroneous record, for Phyllariopsis } \\
\text { breviceps (Sauvageau, 1918; } \\
\text { Feldmann, 1934) }\end{array}$ & Chalon (1900) \\
\hline \multirow[t]{6}{*}{ Italy } & $\begin{array}{l}\text { Genoa (Genova) } \\
\text { (Liguria) }\end{array}$ & $\begin{array}{l}\text { Harbour, on a ship hull, collected } \\
\text { by Baglietto (in Ardissone, 1886) }\end{array}$ & $\begin{array}{l}\text { Ardissone (1886), } \\
\text { Sauvageau (1918), } \\
\text { Feldmann (1934) }\end{array}$ \\
\hline & Portofino (Liguria) & $\begin{array}{l}\text { Collected on shallow reefs in } 1846 \\
\text { by Savignone (in Ardissone, 1886) }\end{array}$ & $\begin{array}{l}\text { Ardissone (1886), } \\
\text { Sauvageau (1918), } \\
\text { Feldmann (1934) }\end{array}$ \\
\hline & $\begin{array}{l}\text { Naples (Napoli) } \\
\text { (Campania) }\end{array}$ & $\begin{array}{l}\text { On a ship hull, in the harbour, in } \\
\text { May } 1907\end{array}$ & $\begin{array}{l}\text { Nienburg in Funk (1927) \& } \\
\text { Funk (1955) }\end{array}$ \\
\hline & $\begin{array}{l}\text { Villa San Giovanni } \\
\text { (Calabria) }\end{array}$ & Harbour jetties & $\begin{array}{l}\text { Molinier \& Picard (1953), } \\
\text { Huvé (1958), Giaccone } \\
\text { (1969) }\end{array}$ \\
\hline & Messina (Sicily) & Harbour jetties & $\begin{array}{l}\text { Huvé (1958), Giaccone } \\
\text { (1969) }\end{array}$ \\
\hline & Messina (Sicily) & On buoy chains, in the liner harbour & $\begin{array}{l}\text { Falkenberg (1879), } \\
\text { Feldmann (1934) }\end{array}$ \\
\hline
\end{tabular}




\begin{tabular}{|l|l|l|l|}
\hline & $\begin{array}{l}\text { Paradiso (Messina, } \\
\text { Sicily) }\end{array}$ & On the chain of a buoy, 22 m depth & $\begin{array}{l}\text { Furnari \& Scammacca } \\
(1973)\end{array}$ \\
\hline Greece & Chios Island & $\begin{array}{l}\text { Observed in 1837 by Chaubard \& } \\
\text { Bory de Saint-Vincent (1838). } \\
\text { Whether it was dredged or found in } \\
\text { the drift matter is unknown. Never } \\
\text { observed again. }\end{array}$ & $\begin{array}{l}\text { Chaubard \& Bory de Saint- } \\
\text { Vincent (1838), Sauvageau } \\
\text { (1918), Feldmann (1934), } \\
\text { Athanasiadis (1987), } \\
\text { Tsiamis } \text { et al. (2013 }\end{array}$ \\
\hline Algeria & Cherchell & $\begin{array}{l}\text { Erroneous record, for Phyllariopsis } \\
\text { breviceps (Feldmann, 1934) }\end{array}$ & Debray (1897) \\
\hline
\end{tabular}

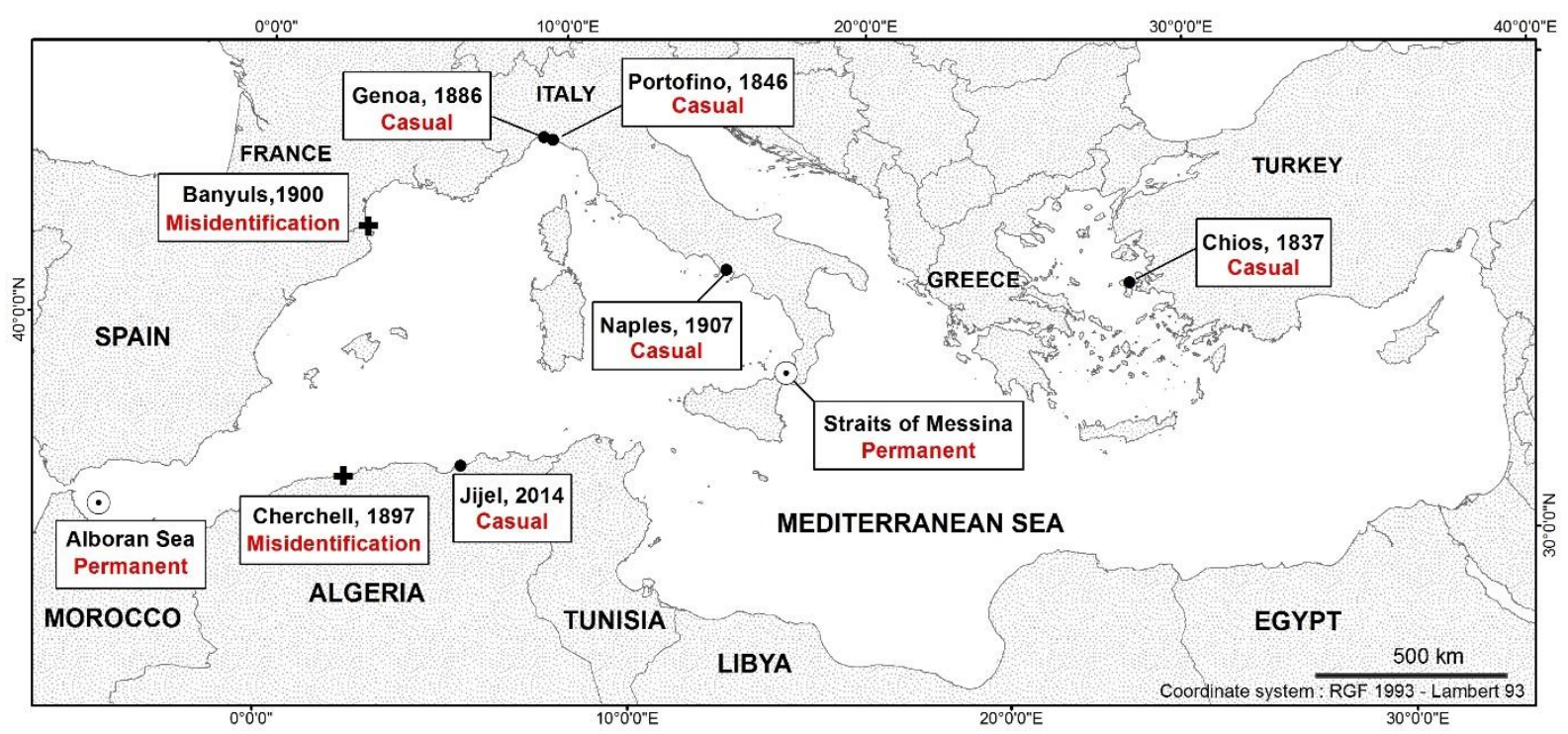

Figure 1. Mediterranean records of Saccorhiza polyschides. The date is that of the sighting and, if unknown, that of the publication.

\section{Results}

In 2014, Souhila Bounail, a student in aquaculture at the EnSSMAL (Algeria), observed a strange brown alga thrown by local artisanal fishers, while cleaning their fishing nets, onto the wharf of the small fishing harbour of El Aouana (formerly cavallo, during the French colonization), c. $15 \mathrm{~km}$ west of Jijel (Fig. 2). The city of Jijel is located $330 \mathrm{~km}$ (by road) and $240 \mathrm{~km}$ (as the crow flies) east of Algiers. Weeasily identified the alga as Saccorhizapolyschides. 


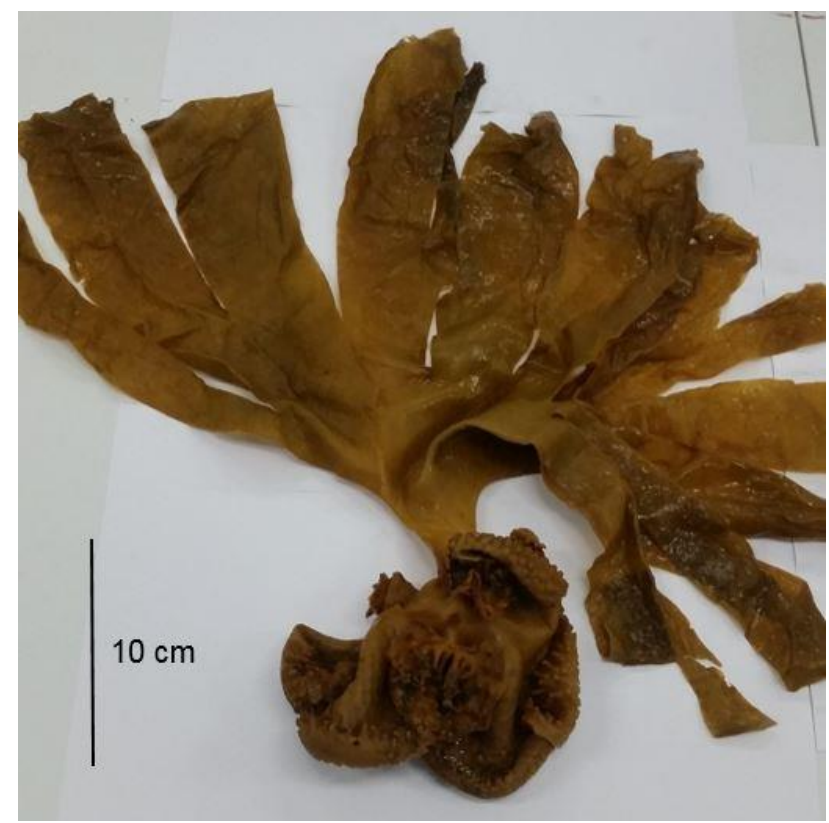

Figure 2. The specimen of Saccorhiza polyschides collected in 2014 at El Aouana (formerly Cavallo), near Jijel, Algeria. Photo (c) Rachid Semroud.

\section{Discussion}

Fishers at El Aouana exploit a $c .10-15 \mathrm{~km}$ range east and west of the harbour. There is therefore little doubt that the alga came from this area. All fishers at El Aouana use fish- ing nets, not trawl, so that the alga probably hooked onto nets at a relatively shallow depth. The very fresh appearance of the seaweed suggests that it was not drift matter carried by the current coming from Gibraltar and the areas of the Alboran Sea where the species is present, more than $1000 \mathrm{~km}$ to the west of Jijel. It is worth noting that drift individuals of S. polyschides do not float. The possibility of spores being driven by currents from cabo tres Forcas (Morocco) or other intermediate (unknown) localities must also be considered. A large part of the world's maritime traffic (c. 30\%) passes through the Mediterranean Sea (dobler 2002).

The main Mediterranean route from Gibraltar to the Suez canal runs along the Algeriancoast(Katsanevakis etal.2014; Grid-Arendal 2019). The port of Jijel, a middle-sized city (c. 150000 inhab- itants), is mainly used by car carriers and bulk cargo vessels. Saccorhiza polyschides can be attached to the hull of ships. A specimen could have detached itself from the hull of a ship in transit in the Jijel region. Another hypothesis is that an ephemeral population of $S$. polyschides may have settled in the vicinity of the port. We did not thoroughly explore the region of Jijel, to attempt to localize a possible source population of S. polyschides. However, such a large species, with charac- teristics that are so striking if compared with other species of the Mediterranean flora, living on relatively shallow hard substrates, could hardly pass unnoticed. We did not obtain any information regarding its presence after 2014. If a stable population did exist, it has since disappeared, as was the case in most of its other Mediterranean localities (Fig. 2).

The main interest of our sighting of S. polyschides near Jijel, and of the review of Mediterranean sightings we present (table 1), is that they shed light on the routes and processes of the range expansion of a species. For most species, due to their small size and to the microscopic nature of their propagules, the flow of propagules, from the margin of their range area towards possible new quarters, is invisible. Failed colonization "attempts" therefore go unnoticed. A large species (several metres tall), dwelling in shallow waters and therefore impossible to miss, $S$. polyschides offers the opportunity to monitor the routes followed by propagules, together with failed "attempts" to establish into new quarters. our review shows that: 1) "attempts" have been uneven over time, with the exception of the early $20^{\text {th }}$ century (no sightings have been recorded in the 20th 
century); The cold 19th century, at the end of the Little Ice Age (Le roy-Ladurie 2004; Gioda et al. 2004; Luterbacher et al. 2004; Le roy-Ladurie 2005), was probably more favourable to the expansion of $S$. polyschides, a warm temperate affinities species (from norway toMorocco; Hoek 1982), than the 20th and 21 st centuries; yet, the flow of propagules, from the Atlantic and the Alboran Sea, to the Mediterranean, is still active, as evidenced by our sighting at Jijel; 2) beachheads have also been uneven. They depend upon the presence of $S$. polyschides on a ship's hull and on the route of a ship towards a port of call. There is therefore no logical pattern of expansion; it follows the "saltation dispersal - hopscotch jump model" rather than the 'diffusion dispersal - wave of advance model'; see e.g. López-Legentil et al. (2015), Boudouresque \& Sempéré (2017), Petrocelli et al. (2018), Verlaque \& Breton (2019). on the basis of genetic tools, the expansion of Dictyota cyanoloma tronholm, de clerck,

A. Gomez-Garetta \& rull Lluch (Phaeophyceae), native to Australia, along the Mediterranean coasts, has been shown to match both the saltation (from harbour to harbour) and the diffusion models (Aragay et al. 2016); and3)range expansion events can prove to be highly uncommon. despite the major current of Atlantic water which enters the Mediterranean at Gibraltar and runs eastwards along the north African coast, only a handful of colonization events have been recorded in more than two centuries.

Fortuitous sightings of supposedly ordinary species may seem uninteresting and not worthy of publication. Yet, they can tell us about important processes in ecology. to understand the current state of the earth and its changes, we need baselines, which are often missing. reporting these observations helps to shed light on future changes.

Acknowledgements. The authors are indebted to Souhila Bounail, who collected the studied specimen, to Enric Ballesteros and an anonymous reviewer for valuable suggestions and to Michel Paul, a native English speaker, for proofreading the manuscript.

\section{References}

ARAGAY J., VITALES D., GÓMEZ GARRETA A., RIBERA SIGUAN M.A., STEEN F., DE CLERCK O., GARNATJE T. \& RULL LLUCH J., 2016 - Phenological and molecular studies on the introduced seaweed Dictyota cyanoloma (Dictyotales, Phaeophyceae) along the Mediterranean coast of the Iberian Peninsula. Mediterranean Marine Science 17(3): 566-776.

ARDISSONE F., 1886 - Phycologia mediterranea. Parte II. Oosporee, Zoosporee, Schizosporee. Tipografia Maj e Malnati, Varese, 325 p.

ARDRÉ F., 1970 - Contribution à l'étude des algues marines du Portugal. I. La flore. Portugaliae Acta Biologica 10(1-4): 1-423 + 56 plates.

ATHANASIADIS A., 1987 - A survey of the seaweeds of the Aegean Sea with taxonomic studies on species of the tribe Antithamniae (Rhodophyta). University of Gothenburg, Department of Marine Botany, $174 \mathrm{p}$.

BALLESTEROS E., SANSÓN M., REYES J., AFONSO-CARRILLO J. \& GILRODRÍGUEZ M.C., 1992 - New records of benthic marine algae from the Canary Islands. Botanica Marina 35, 513-522.

BEAUVOIS A.M.F.J. de, 1805. Flore d'Oware et de Benin, en Afrique, 1. Livraison 2 et 3: 932.

BENHISSOUNE S., BOUDOURESQUE C.F., PERRET-BOUDOURESQUE M. \& VERLAQUE M., 2002 - A check-list of marine seaweeds of the Mediterranean and Atlantic coasts of Morocco. II. Phaeophyceae. Botanica Marina 45: 217-230. 
BOUDOURESQUE C.F., 2015 - Taxonomy and phylogeny of unicellular eukaryotes. In: Environmental microbiology: Fundamentals and applications. Microbial ecology. BERTRAND J.C., CAUMETTE P., LEBARON P., MATHERON R., NORMAND P. \& SIME-NGANDO T. (eds.), Springer publ.: 191-257.

BOUDOURESQUE C.F. \& SEMPÉRÉ R., 2017 - Biological invasions, habitat fragmentation, contamination and ecosystem-based approach in ports and adjacent coastal areas: problems and outlook. In: What knowledge to reconcile the evolution of port facilities with sustainable development in the Mediterranean? Actes du Forum Parmenides VIII, 21-23 March 2017, Genova. GID (Groupement Interdisciplinaire pour le Développement) publ., Paris: 28-32.

BOUDOURESQUE C.F. \& VERLAQUE M., 2012 - An overview of species introduction and invasion processes in marine and coastal lagoon habitats. Cahiers de Biologie Marine 53(3): 309-317.

BOUDOURESQUE C.F., BALLESTEROS E., BEN MAIZ N., BOISSET F., BOULADIER E., CINELLI F., CIRIK S., CORMACI M., JEUDY DE GRISSAC A., LABOREL J., LANFRANCO E., LUNDBERG B., MAYHOUB H., MEINESZ A., PANAYOTIDIS P., SEMROUD R., SINNASSAMY J.M., SPAN A. \& VUIGNIER G., 1990 - Livre rouge "Gérard Vuignier" des végétaux, peuplements et paysages marins menacés de Méditerranée. Programme des Nations Unies pour l'Environnement (UNEP), IUCN publ.: 250 p.

CHALON J., 1900 - Herborisations à Banyuls. Bulletin de la Société Royale de Botanique de Belgique 39: 22-36.

CHAUBARD L.A. \& BORY DE SAINT-VINCENT J.B.J.M., 1838 - Nouvelle flore du Péloponnèse et des Cyclades. F.G. Levrault, Paris, 87 p.

CORMACI M., FURNARI G., CATRA M., ALONGI G. \& GIACCONE G., 2012 - Flora marina bentonica del Mediterraneo: Phaeophyceae. Bolletino dell'Accademia Gioenia di Scienze Naturali di Catania 45(375): 1-510.

DEBRAY F., 1897 - Catalogue des algues du Maroc, d'Algérie, et de la Tunisie. Jourdan publ., Alger, 78 p.

DOBLER J.P., 2002 - Analysis of shipping patterns in the Mediterranean and Black seas. In: Alien marine organisms introduced by ships in the Mediterranean and Black seas, CIESM Workshop monographs 20: 19-28.

FALKENBERG P., 1879 - Die Meeresalgen des Golfes von Neapel. Mittheilungen aus der zoologischen Station zu Neapel, 1: 218-277.

FELDMANN J., 1934 - Les laminariacées de la Méditerranée et leur répartition géographique. Bulletin des Travaux publiés par la Station d'Aquiculture et de Pêche de Castiglione 2 :143-184.

FREDJ G. \& GIACCONE G., 1995 - Particularités des peuplements benthiques du détroit de Messine. In: The Straits of Messina ecosystems, Present knowledge for an ecohydrodynamical approach. Guglielmo L., Manganaro A. \& De Domenico E. (eds.), Università degli Studi di Messina publ.: 119-128.

FUNK G., 1927 - Die Algenvegetation des Golfs von Neapel. Nach neueren ökologischen Untersuchungen. Pubblicazioni della Stazione Zoologica di Napoli 7 (supplemento): 1-507 + 20 plates. 
FUNK G., 1955 - Beiträge zur Kenntnis der Meeresalgen von Neapel zugleich mikrophotographischer Atlas. Pubblicazioni della Stazione Zoologica di Napoli 25 (supplement): i-x, 1-178 +30 plates.

GAYRAL P., 1966 - Les algues des côtes françaises (Manche et Atlantique). Notions fondamentales sur l'écologie, la biologie et la systématique des algues marines. Doin publ., Paris, $632 \mathrm{p}$.

GIACCONE G., 1969 - Note sistematiche ed osservazioni fitosociologiche sulle laminariales del Mediterraneo occidentale. Gionale Botanico Italiano 103 (6): 657-674.

GIODA A., JOMELLI V. \& RABATEL A., 2004 - Petit âge de glace, lichens et archives religieuses. Pour la Science, Dossier 42: 100-103.

GRID ARENDAL, 2019 - Marine transportation routes in the Mediterranean. www.grida.no/resources/5920. Accessed on September 29 ${ }^{\text {th }}, 2019$.

HAMEL G., 1931-1939 - Phéophycées de France. Imprimerie Wolf, Rouen, xlvi + 432 p + 10 plates.

HUVÉ H., 1958 - Contribution à l'étude des peuplements de Phyllariacées du détroit de Messine. Rapports et Procès-Verbaux des Réunions, Commission Internationale pour l'Exploration Scientifique de la mer Méditerranée 14: 525-533.

KATSANEVAKIS S., COLL M., PIRODDI C., STEENBEECK J., BEN RAIS LASRAM F., ZENETOS A. \& CARDOSO A.C., 2014 - Invading the Mediterranean Sea: biodiversity patterns shaped by human activities. Frontiers in Marine Science 1(32): 1-11.

LE ROY-LADURIE E., 2004 - Histoire humaine et comparée du climat. Canicules et glaciers, $X I I I^{\circ}-X V I I I^{\circ}$ siècles. Fayard publ., Paris, 740 p.

LE ROY LADURIE E., 2005 - Canicules, fraîcheurs, vendanges (France, $\mathrm{XV}^{\circ}$-XIX ${ }^{\circ}$ siècles). Compte-Rendus Biologies 328: 213-222.

LÓPEZ-LEGENTIL S., LEGENTIL M.L., ERWIN P.M. \& TURON X., 2015 - Harbor networks as introduction gateways: contrasting distribution patterns of native and introduced species. Biological Invasions 17: 1623-1638.

LUTERBACHER J., DIETRICH D., XOPLAKI E., GROSJEAN M. \& WANNER H., 2004 European seasonal and annual temperature variability, trends and extremes, since 1500. Science 303: 1499-1503.

MOLINIER R. \& PICARD J., 1953 - Notes biologiques à propos d'un voyage d'étude sur les côtes de Sicile. Annales de l'Institut Océanographique 28(4): 163-187 + 4 plates.

NAVARRO M.J. \& GALLARDO T., 1989 - Aportación al conocimiento de la flora bentónica de las costas mediterráneas africanas occidentales. Botanica Complutensis 15: 203214.

NORTON T.A., 1977 - Experiments on the factors influencing the geographical distribution of Saccorhiza polyschides and Saccorhiza dermatodea. New Phytologist 78: 625-635.

NORTON T.A. \& BURROWS E.M., 1969 - Studies on marine algae of the British Isles. 7. Saccorhiza polyschides (Lightf.) Batt. British Phycological Journal 4(1): 19-53.

OULD-AHMED N., GOMEZ GARRETA A., RIBERA SIGUAN M.A. \& BOUGUEDOURA N., 2013 - Checklist of the benthic marine macroalgae from Algeria. I. Phaeophyceae. Anales del Jardín Botánico de Madrid 70(2): 136-143. 
PERRET-BOUDOURESQUE M. \& SERIDI H., 1989 - Inventaire des algues marines benthiques d'Algérie. GIS Posidonie publ., Marseille, $115 \mathrm{p}+1$ plate.

PETROCELLI A., ANTOLIĆ B., BOLOGNINI L., CECERE E., CVITKOVIĆ I., DESPALATOVIĆ M., FALACE A., FINOTTO S., IVEŠA L., MAČIĆ V., MARINI M., ORLANDO-BONACA M., RUBINO F., TRABUCCO B. \& ŽULJEVIĆ A., 2018 - Port baseline biological surveys and seaweed bioinvasion in port areas: what's the matter in the Adriatic Sea? Marine Pollution Bulletin 147: 98-116..

PRICE J.H., JOHN D.M. \& LAWSON G.W., 197 8- Seaweeds of the western coast of tropical Africa and adjacent islands: a critical assessment. II. Phaeophyta. Bulletin of the British Museum Natural History (Botany): 6(2): 87-182.

RIBERA M.A. \& BOUDOURESQUE C.F., 1995 - Introduced marine plants, with special reference to macroalgae: mechanisms and impact. In: Progress in Phycological Research, ROUND F.E. \& CHAPMAN D.J. (eds), Biopress Ltd publ., UK , 11: 187-268.

RIBERA M.A., GOMEZ GARRETA A., GALLARDO T., CORMACI M., FURNARI G. \& GIACCONE G., 1992 - Check-list of Mediterranean seaweeds. I. Fucophyceae (Warming, 1884). Botanica Marina 35: 109-130.

RUENESS J., 1977 - Norsk algeflora. Universitetsforlaget publ., Oslo, 266 p + 32 plates.

SAUVAGEAU C., 1918 - Sur la dissémination et la naturalisation de quelques algues marines. Bulletin de l'Institut Océanographique 342: 1-28.

TSIAMIS K., PANAYOTIDIS P., ECONOMOU-AMILLI A. \& KATSAROS C., 2013 Seaweeds of the Greek coasts. I. Phaeophyceae. Mediterranean Marine Science, 14 (1): 141157.

VERLAQUE M. \& BRETON G., 2019 - Biological invasion: long term monitoring of the macroalgal flora of a major European harbor complex. Marine Pollution Bulletin 143: 228241. 